\title{
THE MANUFACTURING EMPLOYMENT LONGITUDINAL DENSITY DISTRIBUTION IN THE USA
}

\author{
Barry M. Moriarty*
}

\begin{abstract}
This microanalysis of manufacturing employment density-distribution patterns in the United States from 1947 to 1982 reveals that the density of production workers increased with distance from the Manufacturing Belt, while the density of nonproduction workers decreased. The research supports the hypothesis that the nation's hierarchical system of cities has served to sort manufacturing operations geographically on the basis of the returns that could be derived from different sized urban centers. As a consequence of this sorting process, nonproduction workers have become more concentrated in large urban centers, while production workers have become more concentrated in smaller settlements. Because most large urban centers are located in the Northeast and East North-Central regions, nonproduction workers have become more concentrated in the Manufacturing Belt, while production workers have settled primarily in other regions of the country. The process has helped to foster the development of a mosaic of geographically bifurcated labor markets among the larger and smaller urban centers throughout the country. The keywords in this paper include: deindustrialization, industrial restructuring, economic development, manufacturing employment redistribution, urban system, and industrial decentralization.
\end{abstract}

\section{INTRODUCTION}

Industrial production in the United States has been undergoing a geographic redistribution at both interregional and intraregional scales for several decades (Cromley and Leinbach 1981; Erickson 1976; Erickson and Leinbach 1979; Fuguitt and Beale 1984; Garnick 1985; Hansen 1979; Heaton and Fuguitt 1979; Moomaw 1985; Moriarty 1977, 1978, 1980, 1981, 1983, 1986, 1989; Norton and Rees 1979; Park and Wheeler 1983; Rees 1979; Schmenner 1982; Struyck and James 1975; Till 1973; and Zelinsky 1962). One explanation for this geographic filtering of manufacturing is based upon the reorganization of firms' functional operations and the restructuring of investment strategies as whole industries become more and more dominated by multiplant corporations confronted by stagnating sales and progressively rising costs. In the past, many firms had benefitted from the agglomeration economies of core industrial regions; but faced with productivity constraints at different functional levels, the firms have compensated for these former advantages by relocating certain of their operations to different

\footnotetext{
*Professor of Economic Geography, Department of Geography, The University of North Carolina, Chapel Hill. This research was supported by the National Science Foundation under grant numbers SES-8600654 and SES-9100492.
} 
geographic areas where other cost advantages could be substituted (Humphrey 1982). Recent studies have found the changing geographic pattern to be consistent with the "filtering down" hypothesis of industrial location that postulates that "manufacturing diffuses down the hierarchical system of cities from places of greater to lesser labor sophistication" (Hoover 1948, 174-75; Thompson 1969, 5 6).

It is the thesis of this paper that the principal mechanism underlying the geographic filtering of manufacturing within nations can be found in the direct relationships that exist among settlement size, external economies, and wage bills for identical jobs, regardless of the region in which they are performed (Goldfarb and Yezer 1976; Johnson 1983; Moriarty 1978). Since wage levels tend to increase almost automatically with the growth of urban centers (and with plant size), the higher wage bills either price the less competitive firms out of the larger centers or cause them to become more capital intensive in their operations by the adoption of labor-saving process technology (Rees, Briggs, and Oakey 1984). The tradition of industrial, technological innovation in the United States supports this proposition; 40 percent of manufacturing innovations between 1945 and 1974 were labor saving, compared to 13 percent in Europe and 6 percent in Japan (National Science Board 1981). Firms priced out of the larger centers tend to undergo a process of vertical disintegration either by ridding themselves entirely of unproductive operations and relying upon subcontractors for their fulfillment or by locating the operations in smaller centers in more distant areas to take advantage of lower labor, land, and utility costs. The second alternative can be accomplished through the relocation of plant facilities in some cases, through the acquisition of an existing plant in other cases, or through the establishment of a branch plant in most cases. The least competitive labor-intensive industries or operations locate in smaller towns and rural areas in even more peripheral regions or offshore countries that have lower than average wage bills and external economies (English 1983).

The settlement-size, industrial-sorting process can most readily be linked to the product life cycle model in which different inputs and scales of production are required during the different phases of new, improved, and mature product manufacturing (Moriarty 1983; Vernon 1966). According to the model, plants innovating new products were located in large cities; plants producing standardized products were located in small settlements. The product life cycle relationship to city size existed only for about two decades after World War II (Vernon 1979). During the past two decades, many multiplant firms have taken advantage of the returns that can be derived from different sized urban centers, regardless of the life cycle stage of their products. This more up-to-date location model is based on the labor skill-external economy requirements of the individual industrial facility. 
Plants that produce products that are highly dependent upon specialized production techniques using high-cost engineers, technicians, and skilled craftsmen are normally found in the larger urban centers of the nation. A myriad of specialized, producer-service vendors that can quickly supply specialized inputs on short notice is also found in the larger urban centers. The large metropolitan centers of the country tend to be more highly concentrated in the Northeast and Great Lakes core regions of the Manufacturing Belt. Plants that manufacture products by routine processes requiring minimal labor skills locate in smaller settlements with ready access to markets (Erickson 1976; Erickson and Leinbach 1979; Norton and Rees 1979). Most of these facilities require few local inputs or services other than low-cost land, labor, and utilities. ${ }^{1}$ Small cities and towns tend to be dispersed throughout the country.

The spatial implications of both models are straightforward. Certain highlevel functions tend to concentrate in established industrial districts or metropolitan centers of the core regions: the principal management functions, marketing, purchasing, research and development, skilled craft operations, and a number of functions contracted to local suppliers. Here, the ratio of nonproduction workers to production workers is high. Other lower-level fabrication and assembly manufacturing functions tend to concentrate mainly in smaller cities and towns in the core region or in more peripheral areas some distance from the core where low-skilled workers are available. In these areas, the ratio of nonproduction workers to production workers is low. Within each region, as metropolitan centers grow, their external economies expand, and threshold levels are reached capable of supporting new plants oriented to local or regional consumer and intermediate markets. Many of these plants are likely to be in the product innovation stage and require higher-skilled craftsmen and technical and managerial personnel. The effect of growth in both the size and the quality of the labor force increases overall wage bills and forces the less competitive, lower-wage firms and industries into smaller towns or rural areas having lower-than-average wage rates, worker benefits, and external economies. Thus, within each region, the ratio of nonproduction workers to production workers is high in metropolitan centers and low in nonmetropolitan settlements.

Several testable hypotheses derive from the spatial implications of both the product cycle and labor skill-external economy models that are directly related to the geographic redistribution of manufacturing employment. First, the growth of nonproduction employment will be greater in the core regions within nations, while the growth of production employment will be greater within peripheral regions over time. Second, nonproduction employment will tend to grow more in large urban centers, while production employment will tend to expand more in smaller settlements over time. 
This research will examine spatial-temporal changes in manufacturing employment density-distribution patterns from 1947 to 1982 for total manufacturing workers, production workers, and nonproduction workers. The empirical analysis does not require that a distinction be made between the two models.

\section{SPATIAL-TEMPORAL PATTERNS OF MANUFACTURING EMPLOYMENT}

\section{Empirical Patterns}

During the three and one-half decades following World War II (1947-1982), total manufacturing employment in the United States grew by 4.75 million jobs (Table 1). While manufacturing employment increased, its percentage of the total work force declined. Never greater than 30 percent of the work force, manufacturing employment declined from 25 percent of total employment in 1950 to 22 per-

TABLE 1

Changes in Manufacturing Employment by Type and Region: 1947-1982 (in thousands)

\begin{tabular}{|c|c|c|c|c|c|c|}
\hline Region & $\begin{array}{c}\text { Total } \\
\text { Employ- } \\
\text { ment } \\
\text { Change }\end{array}$ & $\begin{array}{c}1947- \\
1967 \\
\text { Pro- } \\
\text { duction } \\
\text { Worker } \\
\text { Change }\end{array}$ & $\begin{array}{c}\text { Non- } \\
\text { pro- } \\
\text { duction } \\
\text { Worker } \\
\text { Change }\end{array}$ & $\begin{array}{c}\text { Total } \\
\text { Employ- } \\
\text { ment } \\
\text { Change }\end{array}$ & $\begin{array}{c}1967- \\
1982 \\
\text { Pro- } \\
\text { duction } \\
\text { Worker } \\
\text { Change }\end{array}$ & $\begin{array}{l}\text { Non- } \\
\text { pro- } \\
\text { duction } \\
\text { Worker } \\
\text { Change }\end{array}$ \\
\hline Manufacturing Belt & $1,396.0$ & -144.3 & $1,540.3$ & $-2,175.7$ & $-2,323.4$ & 146.7 \\
\hline Other United States & $3,535.2$ & $2,155.9$ & $1,379.3$ & $1,973.9$ & 778.9 & $1,195.0$ \\
\hline Total United States & $4,931.2$ & $2,011.6$ & $2,919.6$ & -201.8 & $-1,544.5$ & $1,341.7$ \\
\hline Region & $\begin{array}{c}\text { Total } \\
\text { Employ- } \\
\text { ment } \\
\text { Change }\end{array}$ & $\begin{array}{c}\text { 1947- } \\
1982 \\
\text { Pro- } \\
\text { duction } \\
\text { Worker } \\
\text { Change }\end{array}$ & $\begin{array}{c}\text { Non- } \\
\text { pro- } \\
\text { duction } \\
\text { Worker } \\
\text { Change }\end{array}$ & & & \\
\hline Manufacturing Belt & -779.7 & $-2,467.7$ & $1,687.0$ & & & \\
\hline Other United States & $5,509.1$ & $2,934.8$ & $2,574.3$ & & & \\
\hline Total United States & $4,729.4$ & 467.1 & $4,261.3$ & & & \\
\hline
\end{tabular}

The Manufacturing Belt includes the New England, Mid-Atlantic, and East North-Central census regions plus Delaware and Maryland. The other United States includes the remaining six continental U.S. census regions less Delaware and Maryland in the South Atlantic region. Source: Compiled by author from U.S. Census of Manufacturers. 
cent in 1980. All of the net growth in the three and one-half decade period occurred outside the country's traditional Manufacturing Belt, which includes the New England, Middle Atlantic, and East North-Central census divisions. The Manufacturing Belt experienced a net loss of 750,000 jobs between 1977 and 1982 , while the rest of the country realized a net gain of 5.5 million workers. Nonetheless, the Manufacturing Belt still contained 49 percent of the nation's manufacturing employment in 1982, although down 21 percent from 1972. Ninety percent of the total manufacturing growth was in nonproduction employment, mostly salaried workers engaged in management, sales, research and development, and other support activities. Only 10 percent of the growth was in wage earners directly involved in production. Nonproduction workers accounted for 17 percent of manufacturing employment in 1947 and 35 percent in 1982.

A striking difference, however, occurred throughout this period in the growth of production and nonproduction employment among the nation's regions. While the Manufacturing Belt exhibited a loss of 750,000 workers, the loss represented a net decline of nearly 2.5 million production workers, but a gain of 1.7 million nonproduction workers. On the other hand, the 5.5 million worker gain realized by the rest of the country was nearly evenly divided, with a slightly greater increase in production workers. This gain is noteworthy, since production workers had decreased in importance within the total manufacturing labor force. The trends provide evidence on the macro scale of a growing spatial division of labor in which the Manufacturing Belt had spun off lower income production jobs to other regions of the country while growing in higher income, external control functions (Rees 1978). ${ }^{2}$

\section{Spatial-Temporal Distribution of Manufacturing Employment}

Employment data by state were compiled from the Census of Manufacturers for the eight post-World War II years in which the census was conducted: 1947 , $1954,1958,1963,1967,1972,1977$, and 1982. The data were subdivided into production and nonproduction workers following the census definitions. Auxiliary manufacturing workers were added to the 1954 and 1958 nonproduction worker totals for each state to make the data for these years consistent with censuses conducted after 1958. The number of auxiliary workers existing in 1947 was estimated for each state by a quadratic regression equation using available employment data for census years after 1947. No adjustments were made to account for differences in unemployment rates during different census years that were related to the effects of business cycles. Employment densities were calculated based upon the land area of each state, and the straightline distance between the centroid of each state and New York City was measured. New York City was 
chosen because it occupies the highest level in the nation's hierarchial system of cities and contains a much larger agglomeration of major financial institutions and manufacturing headquarter facilities than any other city in the country (Pred 1977).

A quadratic, negative-exponential distance equation was converted into a terminal model by expansion of the distance variables into linear functions of time to examine the spatial-temporal trends over the period (Casetti 1972, 1983). The employment data were pooled for all eight years. The terminal model is represented by the equation:

$$
L n D_{d t}=L n D_{0}+a_{1} t-b_{0} d+b_{1} t d+c_{0} d^{2}+c_{1} t d^{2}
$$

where:

$$
\begin{aligned}
\mathrm{LnD}_{\mathrm{dt}}= & \left(\log _{\mathrm{e}}\right) \text { density of employment in a manufacturing category } \\
& \text { in a state (per 1,000 square kilometers of land area) at } \\
& \text { distance } \mathrm{d} \text { from New York City for a particular year } \mathrm{t} \\
\mathrm{LnD}_{0}= & \left(\log _{\mathrm{e}}\right) \text { employment density in a manufacturing category } \\
& \text { in the New York City central core area; } \\
\mathrm{t}= & \text { an integer equal to } 1 \text { if the year was } 1947 \text { and up to } 36 \text { if } \\
& \text { the year was } 1982 ; \\
\mathrm{d}= & \text { straight-line distance in kilometers from New York City } \\
& \text { to the centroid of the state; } \\
\mathrm{a}= & \text { a regression coefficient that measures the change in } \\
& \text { employment density with time; } \\
\mathrm{b}= & \text { a regression coefficient that measures the change in } \\
& \text { employment density in the core area; and } \\
\mathrm{c}= & \text { a regression coefficient that measures the change in } \\
& \text { employment density in regions away from the core. }
\end{aligned}
$$

The $b$ coefficient measures the instantaneous rate of change of the density gradient in the core state of New York (Figure 1). It may take negative, zero, or positive values to permit the representation of all possible changes in the core density gradient. When negative, the density surface is declining away from the core state. If employment declines in the core state relative to employment in adjacent states, a flattening of the density surface occurs, causing $b$ to first converge to zero and later become positive as a density crater emerges. The c coefficient measures the degree of curvature of the density gradient away from the core. If $\mathrm{c}$ is zero, no curvature is evident; if $c$ is positive, the curvature is concave to the origin, and the employment density is declining with distance more rapidly in states close to the core than in those further away. If $\mathrm{c}$ is negative, the curvature is 
FIGURE 1

Type I and Type II Spatial-Temporal Gradient Trends

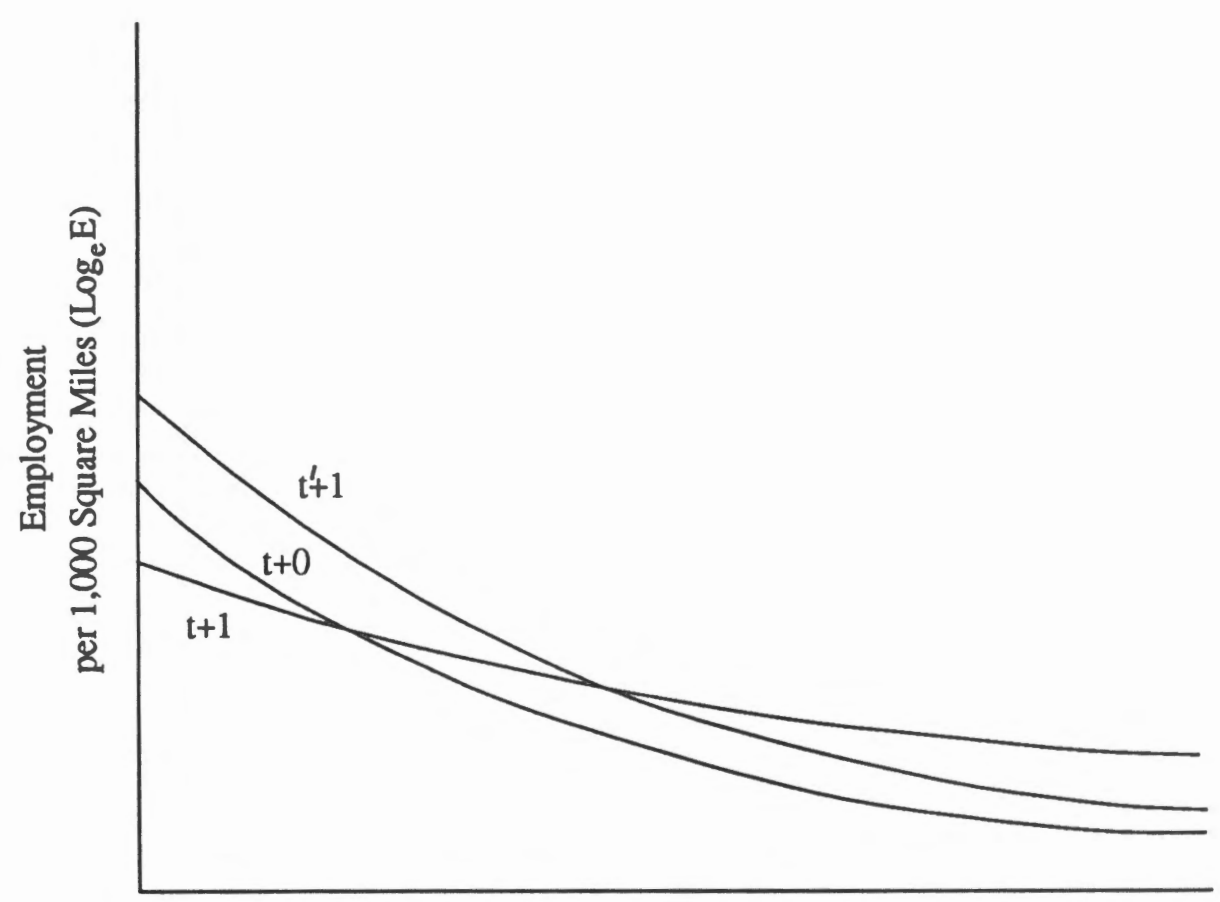

Distance from New York City (d)

convex to the origin, and the employment density is declining less rapidly in core states than in those located in more peripheral regions. The greater the absolute value of $c$, the greater the degree of curvature of the density surface. The employment densities are expressed as natural logarithmic transformations Ln, which tend to compress large employment values considerably more than small values.

The empirical data suggest that two trends have likely occurred in the employment density-distribution patterns: 1) the density of nonproduction workers generally increased in all regions of the country between 1947 and 1982 (represented by a change in the density gradient from $t+0$ to $t^{\prime}+1$ in Figure 2), and 2) the density of production workers declined in the core region and increased in regions outside the core (represented by a change in the density gradient from $t+0$ to $t+1$ in Figure 2). A third trend is a less likely possibility: that the density of production workers in the central core region declined to a degree that was lower than the density of adjacent regions. 
FIGURE 2

Density Gradients from New York City to the West Coast

for Production and Nonproduction Workers for 1947 and 1982

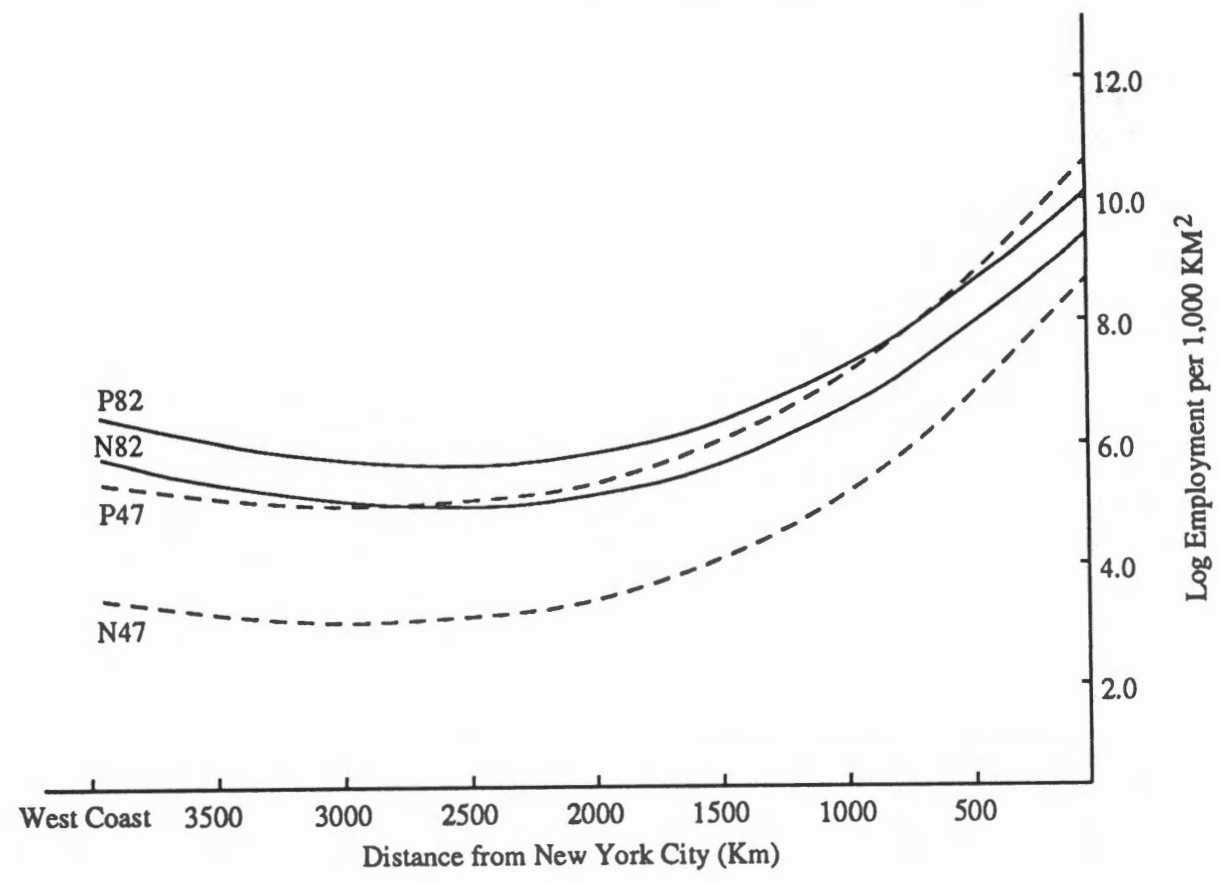

In order for the first trend $\left(t+0\right.$ to $\left.t^{\prime}+1\right)$ to have occurred, the density would have had to increase and the gradient remain constant over time such that:

$$
\frac{\partial L n D}{\partial d}<0, \frac{\partial L n D}{\partial t}>0, \text { and } \frac{\partial}{\partial t}\left(\frac{1}{L n D} \frac{\partial L n D}{\partial d}\right)=0
$$

Spatial-temporal trends of the second type $(t+0$ to $t+1)$ occurred if the density increased, but the gradient became flattened. This trend requires that:

$$
\frac{\partial L n D}{\partial d}<0, \text { and } \frac{\partial}{\partial t}\left(\frac{1}{L n D} \frac{\partial L n D}{\partial d}\right)>0
$$

The third type of trend involves the transformation of the central core density gradient from a cone to a depression and requires a division of the total time period into two intervals, such that:

$$
\frac{\partial L n D}{\partial d}<0 \text { for the first time interval, and }
$$




\section{$\frac{\partial \operatorname{Ln} D}{\partial d} \geq 0$ for the second time interval if $d \frac{\geq}{<} d^{\prime}$; where $d^{\prime}$ is the distance at which $\mathrm{LnD}$ is at its maximum}

The empirical observations that the density distribution of nonproduction workers exhibited a trend of the first type over the three-decade period while production workers exhibited a trend of the second type were tested using the terminal model. The coefficients of the model were estimated by stepwise regression. All regression coefficients that were significantly different from zero were retained if their $\mathrm{t}$ levels of significance were $\leq .05$ (Table 2). The analysis was also performed on the density distribution of nonproduction workers per 100 production workers using the terminal model in its nontransformed format. The coefficients of determination, $\mathrm{R}^{2}$ and $\mathrm{F}$ values for all equations (especially the transformed ones), were substantial, indicating the terminal model provided an excellent mathematical description of the spatial-temporal patterns.

TABLE 2

Regression Analysis of Spatial Temporal Density Distribution Patterns

\begin{tabular}{|c|c|c|c|c|c|c|c|c|c|}
\hline Employment & LnDo & $a(t)$ & $b(d)$ & $c\left(d^{2}\right)$ & $b(t d)$ & $c\left(t d^{2}\right)$ & $\begin{array}{l}\text { Std. } \\
\text { Err. }\end{array}$ & $\mathbf{R}^{2}$ & $\begin{array}{c}\text { Mul- } \\
\text { tiple } \\
\text { F } \\
\end{array}$ \\
\hline $\begin{array}{l}\text { Logo } \\
\text { Total Workers }\end{array}$ & 11.589 & & $\begin{array}{c}-0.572 \mathrm{D}-2 \\
(263.781)\end{array}$ & $\begin{array}{l}0.139 \mathrm{D}-5 \\
(102.326)\end{array}$ & $\begin{array}{r}0.181 \mathrm{D}-4 \\
(11.938)\end{array}$ & & 1.12 & .67 & 22.081 \\
\hline $\begin{array}{l}\text { Loge }_{\text {e }} \\
\text { Production } \\
\text { Workers }\end{array}$ & 11.290 & & $\begin{array}{c}-0.562 \mathrm{D}-2 \\
(257.675)\end{array}$ & $\begin{array}{r}0.137 \mathrm{D}-5 \\
(99.705)\end{array}$ & $\begin{array}{r}0.152 \mathrm{D}-4 \\
(8.498)\end{array}$ & & 1.12 & .67 & 226.218 \\
\hline $\begin{array}{l}\text { Loge } \\
\text { Nomproduction } \\
\text { Workers }\end{array}$ & 9.559 & $\begin{array}{r}0.352 \mathrm{D}-1 \\
(27.934)\end{array}$ & $\begin{array}{r}-0.549 \mathrm{D}-2 \\
(234.787)\end{array}$ & $\begin{array}{l}0.145 \mathrm{D}-5 \\
(100.283)\end{array}$ & & & 1.18 & .65 & 201.858 \\
\hline $\begin{array}{l}\text { Nonproduction } \\
\text { Workers per } 100 \\
\text { Production } \\
\text { Workers }\end{array}$ & 25.935 & $\begin{array}{r}0.616 \mathrm{D}-0 \\
(81.747)\end{array}$ & $\begin{array}{r}-0.743 \mathrm{D}-2 \\
(4.096)\end{array}$ & $\begin{array}{r}0.372 \mathrm{D}-5 \\
(6.313)\end{array}$ & & & 12.08 & .21 & 30.164 \\
\hline
\end{tabular}

Source: Author. $\mathrm{t}$ values in parenthesis.

The values of $\frac{\partial \operatorname{Ln} D}{\partial d}$ in all the regression results were clearly negative for all distances throughout the 35-year period, which eliminated the occurrence of trends of the third type. For total manufacturing employment density, 


$$
\frac{\partial}{\partial t}\left(\frac{1}{\operatorname{Ln} D} \frac{\partial L n D}{\partial d}\right)=0.000009
$$

and for production worker density,

$$
\frac{\partial}{\partial t}\left(\frac{1}{\operatorname{Ln} D} \frac{\partial \operatorname{Ln} D}{\partial d}\right)=0.0000076
$$

The derivatives were greater than zero both geographically and temporally, verifying the flattening of the density gradient for total manufacturing workers and production workers represented by a type-two trend. For nonproduction workers and the ratio of nonproduction workers per 100 production workers,

$$
\frac{\partial}{\partial t}\left(\frac{1}{\operatorname{Ln} D} \frac{\partial \operatorname{Ln} D}{\partial d}\right)=0
$$

thus verifying the overall increase in the density-distribution gradient represented by a type-one trend.

It should be noted that the regression coefficients associated with the density of nonproduction workers per 100 production workers declined significantly with distance from New York City over the 35-year period with a pronounced curvature convex to the origin, confirming the growing concentration of nonproduction workers in core regions compared to peripheral regions.

\section{THE URBAN HIERARCHICAL DISTRIBUTION OF MANUFACTURING EMPLOYMENT}

The expanded second-degree negative exponential equation, while providing a "good fit" to the data, has limitations in its ability to describe adequately manufacturing employment density distributions. Distance squared $\left(d^{2}\right)$, the variable designed to account for the geographic spread of the distribution, possesses several methodological and theoretical problems. Methodologically, it is highly collineated with distance, resulting in the probable underestimation of the regression coefficients. Its use does little to eliminate the presence of positive spatial autocorrelation often found in the residuals of regression models employing geographically arrayed data, which leads to the probable overestimation of the regression coefficients. Theoretically, it does not contribute information about other salient factors involved in the geographic distribution of manufacturing employment, nor does it answer how the factors may be functionally related to 
distance and to each other. It does nothing, for example, to examine the spatial filtering of manufacturing that is postulated to be associated with the nation's hierarchical system of cities.

\section{Measurement of Urban Hierarchical Structure}

Methodological and theoretical problems can be resolved by replacing $\mathrm{d}^{2}$ with other measures that describe the influence of the urban system on the spread of manufacturing employment. It is well known that a significant mathematical relationship exists between the various sizes of cities and number of cities in each size category within a region, such that the number of cities $\mathrm{N}$ in each category is inversely related to the population size S of the category (Beguin 1985; Parr 1970, 1983, 1985c; and Table 3). Expressed in a linear format, the relationship is:

$$
\operatorname{LnS}_{\mathrm{N}}=\mathrm{LnS}_{1}-\mathrm{BLnN}
$$

where:

$$
\begin{aligned}
\mathrm{LnS}_{N}= & \left(\log _{e}\right) \text { median population size of each city-size category in } \\
& \text { a state (the categories }=1,2, \ldots, 12) ; \\
\mathrm{LnS}_{1}= & \begin{array}{l}
\left(\log _{e}\right) \text { median population size of the largest city-size } \\
\text { category in a state; }
\end{array} \\
\mathrm{LnN}= & \begin{array}{l}
\left(\log _{e}\right) \text { number of cities in a state belonging to a particular } \\
\text { size category; and }
\end{array} \\
\mathrm{B}= & \begin{array}{l}
\text { a regression coefficient that measures the relative dominance } \\
\text { of lower-order settlements in a state's urban system. }
\end{array}
\end{aligned}
$$

Thus, $\mathrm{LnS}_{1}$ represents the size of the largest cities in the urban system of each state, and B defines the hierarchical structure of the state's system. Since B is negative in all cases, large values of $B(-1.0)$ represent many small places with respect to the largest cities, while small values of $B(-2.0)$ represent few small settlements with respect to the largest centers.

The parameters were estimated for each of 48 states for four years-1950, 1960, 1970, and 1980-from Census of Population data. In each year, 70 percent of the states yielded coefficients of determination greater than $r^{2}=.90$ between the size and number of cities. Ninety percent of the states produced coefficients greater than $r^{2}=80$. Nevada, North Dakota, and Rhode Island were the only states consistently below $r^{2}=.70$. A sensitivity analysis of $\mathrm{LnS}_{1}$ and B revealed that they were significantly related to a sample of factors that characterized a state's degree of urbanization and to the level of external economies and labor market conditions 
TABLE 3

United States City-Size Distributions

\begin{tabular}{crrrr}
\hline \hline $\begin{array}{c}\text { SIZE CATEGORY } \\
(000)\end{array}$ & \multicolumn{5}{c}{ NUMBER OF CITIES } \\
\hline 1950 & \multicolumn{1}{c}{1960} & 1970 & 1980 \\
\hline $2,500-5,000$ & 1 & 1 & 2 & 1 \\
$1,000-2,500$ & 1 & 1 & 2 & 1 \\
$500-1,000$ & 3 & 3 & 3 & 4 \\
$250-500$ & 13 & 16 & 20 & 16 \\
$100-250$ & 23 & 29 & 29 & 33 \\
$50-100$ & 65 & 81 & 100 & 116 \\
$25-50$ & 126 & 201 & 240 & 290 \\
$10-25$ & 252 & 429 & 516 & 669 \\
$5-10$ & 778 & 1,130 & 1,378 & 1,756 \\
$2.5-5$ & 1,176 & 1,390 & 1,822 & 2,178 \\
$1.0-2.5$ & 1,846 & 2,128 & 2,270 & 2,636 \\
TOTAL & 4.615 & 4,711 & 4.788 & 5,412 \\
& 8,899 & 10,120 & 11,170 & 13,112 \\
\hline
\end{tabular}

Source:Compiled by author from United States Census of Population.

Data pertain to the continental U.S. only.

found in different sized settlements, regardless of the regions in which they were located (Table 4). The multicollinearities between $\mathrm{LnS}_{1}, \mathrm{~B}$, and distance from New York City d were negligible.

\section{Urban Structure and Changes in the Pattern of Employment}

The change in the number of total manufacturing workers, production workers, and nonproduction workers per 1,000 square kilometers was obtained for the periods 1947-1967, 1967-1982, and 1947-1982, with the first period representing the product cycle model and the second period representing the labor skill-external economy model. The relationships among the urban structure indices ( $\mathrm{LnS}_{1}$ and $\mathrm{B}$ ), distance (Lnd) from New York City, and the employment density changes $(\Delta D)$ were examined by regression analysis, along with an additional variable (A) to correct for the positive spatial autocorrelation found in the regression residuals during preliminary investigations (Table 5).

$$
\Delta D_{d}=\Delta D_{0} \pm b_{1} L n d \pm b_{2} L n S_{1} \pm b_{3} B \pm b_{4} A
$$

The residuals indicated a directional bias between the 24 northern-tier Frost Belt states and the 24 southern-tier Sun Belt states in which total employment 
TABLE 4

Correlation Analysis of Urban System Indices with Characteristics of Labor and External Economies

\begin{tabular}{lllll}
\hline \hline & LnS1 & Sign.F & B & Sign.F \\
\hline Engineers and nonhealth & & & & \\
$\quad$ technicians per 100 workers & .43 & $(.001)$ & -.61 & $(.000)$ \\
Percent rural population & -.65 & $(.000)$ & .46 & $(.000)$ \\
Manufacturing wage rate & .30 & $(.019)$ & -.11 & $(.231)$ \\
Percent state unionized & .31 & $(.016)$ & -.05 & $(.363)$ \\
Business service revenues & .61 & $(.000)$ & .05 & $(.367)$ \\
Industry mix & .30 & $(.021)$ & -.32 & $(.014)$ \\
Work stoppage days per & & & & \\
$\quad$ production worker & .62 & $(.000)$ & .07 & $(.330)$ \\
& & & & \\
\hline
\end{tabular}

Source: Author

growth in the Frost Belt was subject to averestimation, while that in the Sun Belt was underestimated. To correct the spatial autocorrelation problem, a new variable $A$ was included in the equation in which $A=1$ if a state was located in the 24state Sun Belt area, and $A=-1$ if a state was located in the 24-state Frost Belt area. Using this approach, everything else being constant, if $b_{4}$ is positive, the Sun Belt states were growing more in employment than the Frost Belt states. On the other hand, if $b_{4}$ is negative, the Frost Belt states were growing more than the Sun Belt states. $^{3}$

The first important finding was that many of the variables associated with the geographic pattern of manufacturing employment had less significance until total employment was broken down into the two labor force components of production workers and nonproduction workers. The estimated equations permit an interpretation of the contribution that each independent variable makes to a state's employment change per 1,000 square kilometers. Discounting the effect of the other variables on the value, the central core area in the vicinity of New York City declined by 1,716 total manufacturing workers per 1,000 square kilometers between 1947 and 1982 (Table 5). ${ }^{4}$ With each unit of distance (Lnd) from New York City, the employment grew by 387 workers. With each unit increase in the slope coefficient (B), describing a state's urban hierarchical structure, total employment declined by 2,244 workers. Since the slope coefficient is a negative value and the regression coefficient is positive, the less steep the slope (indicating a large number of small settlements in a state relative to the largest settlement), the less was the loss in the total number of workers. Over the 35-year period, each unit increase in city size was associated with an increase of 149 workers, while 
TABLE 5

Regression Analysis of Distance, Direction, and Urban Structure Indices on Employment Density Changes: 1947-1982

\begin{tabular}{|c|c|c|c|c|c|c|c|c|}
\hline \multicolumn{9}{|c|}{$1947-1982$} \\
\hline Employment & $\mathrm{D}_{0}$ & Lnd & $\mathrm{LnS}_{1}$ & B & A & $\begin{array}{l}\text { Std. } \\
\text { err. }\end{array}$ & $\mathrm{R}^{2}$ & $\begin{array}{c}\text { tiple } \\
\text { F }\end{array}$ \\
\hline Total workers & $\begin{array}{r}-1,716 \\
(0.36)\end{array}$ & $\begin{array}{r}387 \\
(1.01)\end{array}$ & $\begin{array}{r}149 \\
(0.48)\end{array}$ & $\begin{array}{l}2,244 \\
(1.73)\end{array}$ & $\begin{array}{r}891 \\
(2.74)\end{array}$ & 2,161 & .24 & 3.44 \\
\hline Production workers & $\begin{array}{r}-7,476 \\
(1.40)\end{array}$ & $\begin{array}{l}1,856 \\
(4.29)\end{array}$ & $\begin{array}{r}-103 \\
(0.29)\end{array}$ & $\begin{array}{l}4,563 \\
(3.11)\end{array}$ & $\begin{array}{l}1,049 \\
(2.86)\end{array}$ & 2,440 & .52 & 11.62 \\
\hline Nonproduction workers & $\begin{array}{l}5,760 \\
(1.80)\end{array}$ & $\begin{array}{r}-1,469 \\
(5.68)\end{array}$ & $\begin{array}{r}252 \\
(1.20)\end{array}$ & $\begin{array}{r}-2,319 \\
(2.64)\end{array}$ & $\begin{array}{r}-157 \\
(0.71\end{array}$ & 1,459 & .54 & 12.46 \\
\hline
\end{tabular}

1947-1967

\begin{tabular}{|c|c|c|c|c|c|c|c|c|}
\hline Employment & Do & Lnd & $\mathrm{LnS}_{1}$ & B & A & $\begin{array}{l}\text { Std. } \\
\text { err. }\end{array}$ & $\mathrm{R}^{2}$ & $\begin{array}{c}\text { tiple } \\
\text { F } \\
\end{array}$ \\
\hline Total v & $\begin{array}{r}2,087 \\
(0.43)\end{array}$ & $\begin{array}{r}-686 \\
(1.89)\end{array}$ & $\begin{array}{r}542 \\
(1.94)\end{array}$ & $\begin{array}{c}2,672 \\
(2.19)\end{array}$ & $\begin{array}{r}-330 \\
(1.09)\end{array}$ & 2,001 & .21 & \\
\hline Production workers & $\begin{array}{r}-242 \\
(0.07)\end{array}$ & $\begin{array}{r}280 \\
(4.84)\end{array}$ & $\begin{array}{r}292 \\
(1.63)\end{array}$ & $\begin{array}{r}4,538 \\
(2.79)\end{array}$ & $\begin{array}{r}519 \\
(1.14)\end{array}$ & 1,482 & .45 & \\
\hline Nonproduction workers & $\begin{array}{r}2,329 \\
(0.87)\end{array}$ & $\begin{array}{r}-966 \\
(4.84)\end{array}$ & $\begin{array}{r}250 \\
(1.63)\end{array}$ & $\begin{array}{r}-1,866 \\
(2.79)\end{array}$ & $\begin{array}{r}-189 \\
(1.14)\end{array}$ & 1,098 & .55 & 13. \\
\hline
\end{tabular}

1967-1982

\begin{tabular}{lrrrrrrrr} 
Employment & \multicolumn{1}{c}{ Do } & Lnd & \multicolumn{1}{c}{$\mathrm{LnS}_{1}$} & \multicolumn{1}{c}{ B } & A & $\begin{array}{l}\text { Std. } \\
\text { err. }\end{array}$ & $\mathrm{R}^{2}$ & $\begin{array}{c}\text { Mul- } \\
\text { tiple }\end{array}$ \\
\hline Total workers & -662 & 993 & -454 & 954 & 597 & 995 & .66 & 20.81 \\
& $(0.30)$ & $(5.63)$ & $(3.17)$ & $(1.60)$ & $(3.99)$ & & & \\
Production workers & $-2,418$ & 1,332 & -451 & 1,847 & 601 & 1,189 & .67 & 22.19 \\
& $(0.93)$ & $(6.32)$ & $(2.64)$ & $(2.58)$ & $(3.36)$ & & & \\
Nonproduction workers & 1,756 & -339 & -3 & -894 & -4 & 484 & .38 & 6.67 \\
& $(1.65)$ & $(3.95)$ & $(0.05)$ & $(3.07)$ & $(0.05)$ & & &
\end{tabular}
Source: Author. $\mathrm{t}$ values in parenthesis. For two-tailed test: $\mathrm{t}_{.01}=2.68, \mathrm{t}_{.05}=2.01, \mathrm{t}_{.10}$
$=1.68$.

states in the Sun Belt grew by 891 workers per 1,000 square kilometers more than did states in the Frost Belt. Most of the independent variables, however, yielded a poor fit to the pattern of total worker change with the exception that a state's location in the Sun Belt or Frost Belt exhibited a significant relationship as, perhaps, did its hierarchical structure. Distance from the country's major metropolitan center was not significant to total employment change, nor was the relationship to urban size. 
Separating total employment into production and nonproduction workers yielded more significant but entirely contrasting results. Again, discounting the effects of the values of other variables, the number of production workers $\left(\Delta D_{0}\right)$ declined in the central core area over the three and one-half decades $(-7,476)$, while it increased for nonproduction workers $(5,760)$. The growth in the number of production workers increased with distance from the major metropolitan center, but decreased for nonproduction workers, both very significantly. Urban size $\left(\mathrm{LnS}_{1}\right)$ was not a significant influence on the pattern of change, although it is of interest that a direct relationship existed between city size and the growth of nonproduction workers, but that an inverse relationship existed for the change in production workers-evidence of percolating up the urban hierarchy for nonproduction workers and filtering down the hierarchy for production workers. The hierarchial structure variable (B) exerted a significant influence on the pattern of change: production worker growth was greatest in states having a large number of small settlements, but nonproduction worker growth was significantly deficient in such states. Nonproduction worker growth was more likely to occur in states with a small number of small settlements relative to large urban centers, whereas the same states exhibited little growth in production workers. Because of the few small settlements found in these states, it is most likely that they already contained a sufficient amount of industrial development. It is also clear that the Sun Belt states attracted a significant amount of the growth of production workers, but that the Frost Belt states attracted a greater share of the nonproduction workers, although not in a statistically significant fashion.

Contrasting the two periods (1947-1967 and 1967-1982) yielded some important differences. The number of total manufacturing workers increased in the central core area around New York City during the early period but declined in the later period. In both periods, however, the central core area lost production workers, while the number of nonproduction workers grew. The trend was more significant in the later period. Growth in the total number of manufacturing workers declined with distance in the early period but increased with distance, in the more recent period. Again, the significant differences were associated with differences in the locational patterns of production and nonproduction workers: for both periods the growth in production workers increased with distance while for nonproduction workers it decreased. In other words, the greater the distance from the New York City core region, the greater was the growth in the number of production workers; and the closer the distance, the greater was the growth in nonproduction workers. Over the two periods, the trend intensified for production workers but was mollified for nonproduction workers. A direct relationship existed between city size and all three employment categories in the early period, while an inverse relationship existed for all three categories in the more current 
period. The more current period relationship associated with nonproduction workers, however, was extremely weak and totally lacking in statistical confidence. The direction of the relationships point to a major geographic difference between the two periods: the tendency for manufacturing to have percolated up the urban hierarchy in the early period but to have filtered down the hierarchy more recently-evidence of the locational impact of industrial restructuring. The urban structure coefficient exhibited the same significant relationships for both components of the total time period: production worker growth was associated with states having large numbers of small settlements, and nonproduction worker growth was associated with states having small numbers of such settlements. During both time periods, Sun Belt states also attracted a greater relative number of production workers, while Frost Belt states gained a greater relative share of nonproduction workers. During the later period, this trend was highly significant for production workers but amounted to an insignificant number of nonproduction workers, especially when contrasted with the earlier period.

\section{Partial Correlation Analysis of Employment Changes}

The employment-density changes were subjected to a partial correlation analysis to reveal either the masking or spurious effects of variables when controlling for the effects of other variables. No important masking or spurious effects were uncovered when controlling for the effects of individual variables. The influence of distance from New York City on the growth of both production and nonproduction workers was a slightly less important factor in the early period when controlling for the effects of city size, hierarchical structure, and area of the country, but it became a more important factor in the more recent period. City size was found to be a slightly more significant factor associated with the change in the number of workers in all three employment categories when controlling for distance from New York City, but it became slightly less significant when controlling for the effects of hierarchical structure. The hierarchical structure index revealed a similar pattern: it was also slightly more significant when controlling for distance but less so when controlling for city size. The results indicate a small degree of interaction between city size, hierarchical structure, and distance.

It was evident from the analysis that the relationships among the growth of nonproduction workers and $\mathrm{LnS}_{1}$ and $\mathrm{B}$ suggest increasing returns to scale in urbanized states over the entire time period, but that the relationships between the growth in production workers and the indices indicate decreasing returns to scale in such states. Thus, labor productivity increased overall with the growth in the urban system for nonproduction workers but decreased overall for production workers (Bequin 1983). Labor productivity improvements for production workers 
could best be achieved by locating in less urbanized states dominated by smaller settlements.

\section{CONCLUSIONS}

During the two decades following World War II, most analyses of industrial location ranked market orientation well ahead of labor orientation as a location factor-a response to the circumstances of a boom period in which industry was fulfilling a backlog demand for durable goods (Thompson and Matilla 1959). During this period, investment strategies concentrated on product diversification, with a number of new plants established in the Manufacturing Belt, along with many others located in other regions of the country, most of which were branch plants producing multiple, standardized products for growing regional markets. The typical location strategy of multiplant firms at the time was embodied in the product cycle model's relationship between product stage and city size. Since the mid-1960s, the demand for durable goods has slackened, and labor has become the main location factor (Moriarty 1983). During this more recent period, increased import competition, improved transportation, communications, material and process technologies, and changes in firm organization and management practices have led to an industrial restructuring that has resulted in investment strategies being concentrated on geographic diversification in which different functional operations are located in places offering the most favorable returns on capital investment: labor skill-external economy strategies learned from the location experience provided by the product cycle model.

Throughout the three and one-half decades, the interregional locational shifts of a substantial amount of manufacturing activity in the United States can be related to the more rapid growth of consumer and intermediate markets in the Southern and Western regions of the country compared to the slow-growth trends of the Manufacturing Belt. The locational shifts from metropolitan to nonmetropolitan areas, coupled with the evidence of low rates of capital investment in equipment, and productivity growth in this country compared to other advanced industrial economies since the mid-1960s, indicate that many firms were reducing costs by locating significant production facilities in smaller settlements. This evidence is also supported by the locational shifts of production and nonproduction workers (National Science Board 1981). In a few cases, such facilities were process plants manufacturing components for other plants in the same firm. In most cases, they were plants that produced a single product only (albeit in degrees of diversification) for all the firm's markets (Schmenner 1982). The empirical evidence suggests such a location strategy was employed by a significant number 
of large multiplant firms in which many of the linkages that are external to single plant firms have been internalized within the multiplant corporation, the faster growing manufacturing enterprises. Many firms would never have been able to locate their facilities in smaller settlements if it were not for the massive buildup of federal government infrastructure programs, including the Rural Electrification Act of 1937, which did not become effective until after World War II, and the Federal Highway Act of 1956. Such programs proliferated each decade until the 1980s (Moriarty 1980, chap. 4). The government programs resulted in the more even geographic distribution of infrastructure among larger and smaller settlements within different regions of the country. In 1950, the elimination of base point and other discriminatory regional freight rates that had favored Manufacturing Belt states was also an aid to industrial decentralization.

That the nation's system of cities has exerted an influence on the manufacturing employment density-distribution patterns is clearly evident from the empirical, macroanalyses presented in this research. Within each region of the nation, the geographic pattern of settlements takes the form of a spatial hierarchy of different sized places in which successively smaller communities are more limited in their external economies, labor force skills, and levels of worker compensation. As a result, the hierarchial system serves to sort manufacturing operations geographically on the basis of the returns that can be derived from different sized urban centers. This sorting is aided by the fact that wage bills not only increase for identical jobs with city size, but with plant size as well. Consequently, a Heckshcher-Ohlin comparative-advantage effect exists whereby small plants with average wage bills lower than those of large plants are more cost efficient in large metropolitan centers that have higher average labor costs. Large plants, on the other hand, with higher average wage bills than small plants, are more cost efficient in small settlements with their lower average labor costs (Moomaw 1985). This comparative advantage is further conditioned by the plant's external requirements. Plants requiring linkages to suppliers of various services, components, and process (external to the firm) will tend to locate in large urban areas; those that do not can operate more efficiently in smaller places.

Most studies have not found an association between plant size and city size, except for Norcliffe's 1975 study of a bygone period. More recent evidence suggests an emerging inverse relationship. Of 220 facilities belonging to Fortune 500 firms newly located in the Manufacturing Belt between 1972-1978, 73 were located in metropolitan areas and employed an average of 174 workers, while 147 were located in nonmetropolitan areas and employed an average of 198 workers (Schmenner 1982). The labor-draw areas of small communities have increased considerably over the past 35 years as a result of increased automobile ownership, which is a significant change allowing larger plants to locate in more rural areas. 
This research, however, is not arguing for a strict relationship between plant size and city size, but rather that the settlement-size sorting process is contingent upon a plant's function and requirements for external localization economies.

As a consequence of the settlement-size sorting process, production workers have become more concentrated in smaller settlements, while nonproduction workers have become more concentrated in large urban centers; and since a greater relative number of large urban centers exist in the Manufacturing Belt, production workers have become more decentralized throughout the country, while nonproduction workers have become more concentrated in the Manufacturing Belt. Hence, the density distribution of manufacturing workers and the ratio of nonproduction to production workers exhibit a strong pattern of distance-decay from the central core region. The more recent evidence indicates that as metropolitan centers outside the Manufacturing Belt grow in the quantity and quality of their labor forces and external economies, they have attracted a greater concentration of nonproduction works. As a problematic outcome of the settlement-size sorting process, a mosaic of geographically bifurcated labor markets - a spatial division of labor-has developed among the larger and smaller settlements throughout the country, resulting in states and regions with a large number of smaller settlements having lower than average manufacturing wage rates. The analysis also suggests that the filtering-down hypothesis, long associated with the decentralization of industry, should be reformulated. The creation of nonproduction functions in higher-ordered places in the nation's urban hierarchy was as evident in the research as was the filtering-down of production functions.

\section{ENDNOTES}

1. Product research and development can take place in these smaller settlements through the use of computer networking and one-day delivery service. For the most part, these facilities are associated with multiplant firms, and the smalltown locations are associated with amenities that will attract professional and technical workers to the area.

2. While the peripheral regions added a greater share of the total new nonproduction jobs in the country throughout the 35-year period, the amount was considerably outweighed by their increase in new production jobs when taking into account the substantial loss of production jobs in the Manufacturing Belt. That the growth in nonproduction jobs in the peripheral regions was greater than in the Manufacturing Belt is of importance, but less so than the dramatic substitution of a large number of nonproduction jobs for production jobs in the traditional manufacturing regions. The issue is not an examination of growth patterns per se, 
but an analysis of locational adjustments that portray the restructuring of a large number of industrial sectors.

3. Since $d^{2}$ was estimated from Equation 3, the nontransformed employment-density value (D) was used, rather than the log value (LnD) so that the estimated number of workers could be determined directly, which necessitated that the log value of distance (Lnd) be used in Equation 3 rather than the nontransformed value used in Equation 1.

4. Determining the exact value of the employment density at any distance, including the core area in the vicinity of New York City, requires setting the log distance equal to zero in the estimating equation, $\log S$ and $B$ equal to their values for New York State, and A equal to minus one.

\section{REFERENCES}

Bequin, H. "City-Size Distribution, Consumption Structure, and Labor Productivity: Modeling and Simulation Results." Geographical Analysis 15 (1983): 156-163.

. "A Property of the Rank-Size Distribution and its Use in an Urban

Hierarchy Context." Journal of the Regional Science Association 25 (1985): 437-441.

Casetti, E. "Testing for Spatial-Temporal Trends: an Application to Urban Population Density Trends Using the Expansion Method." Canadian Geographer 17 (1973): 127-137. . "Mathematical Modeling and the Expansion Method." In Statistics for Geographers and Social Scientists, edited by R. B. Mandal, 81-95. New Delhi: Concept Publishing Co., 1982.

Cromley, R., and T. R. Leinbach. "The Pattern and Impact of the Filter-Down Process in Nonmetropolitan Kentucky." Economic Geography 57 (1981): 108-224.

English, C. W. "How Small Towns Steal Jobs from Cities." U.S. News and World Report 94, no. 11 (1983): 61-62.

Erickson, R. A. "The Filtering-Down Process: Industrial Location in a Non-Metropolitan Area." Professional Geographer 28 (1976): 254-260.

Erickson, R. A., and T. R. Leinbach. "Characteristics of Branch Plants Attracted to Nonmetropolitan Areas." Nonmetropolitan Industrialization, edited by R.E. Lonsdale and H.L. Seyler, 57-78. Washington, D.C.: V.H. Winston and Sons, 1979. 
Fuguitt, G. V., and C. L. Beale. "Changes in Population, Employment and Industrial Composition in Nonmetropolitan America." Madison, Wis.: University of Wisconsin Center for Demography and Ecology, 1984.

Garnick, D. H. "Patterns of Growth in Metropolitan and Nonmetropolitan Areas: An Update." Survey of Current Business 65 (1985): 33-38.

Goldfarb, R. S., and A. M. J. Yezer. "Evaluating Alternative Theories of Intercity and Interregional Wage Differentials." Journal of Regional Science 16 (1976): 345-64.

Hansen, N. "The New International Division of Labor and Manufacturing Decentralization in the United States." Review of Regional Studies 9 (1979): 1-11.

Heaton, T. B., and G. V. Fuguitt. "Nonmetropolitan Industrial Growth and Net Migration." Nonmetropolitan Industrialization, edited by R. E. Lonsdale and H.L. Seyler, 119-136. Washington, D.C.: V.H. Winston and Sons, 1979.

Hoover, E. M. The Location of Economic Activity. New York: McGraw-Hill, 1948.

Humphreys, G. "Power and Industrial Structure." The UK Space: Resources Environment and the Future, edited by J. W. House. London: Wiedenfeld and Nicholson, 1982.

Johnson, G. E. "Intermetropolitan Wage Differentials in the United States." The Measurement of Labor Cost, edited by J. Triplett, 309-332. Chicago: University of Chicago Press, 1983.

Moomaw, R. L. "Firm Location and City-Size: Reduced Productivity Advantages as a Factor in the Decline of Manufacturing in Urban Areas." Journal of Urban Economics 17 (1985): 73-89.

Moriarty, B. M. "Manufacturing Wage Rates, Plant Location and Plant Location Policies." Popular Government 43 (1977): 48-53.

"A Note on Unexplained Residuals in North-South Wage Differential Models." Journal of Regional Science 18 (1978): 105-108. Industrial Location and Community Development. Chapel Hill, N. C.: The University of North Carolina Press, 1980.

"Spread and Diffusion Processes in Regional Industrial Employment Growth." Regional Development Under Stagnation, edited by W. Buhr and P. Friedrich. Baden-Baden, Germany: Nomos-Verlag, 1981.

"Hierarchies of Cities and the Spatial Filtering of Industrial Development." Papers: Regional Science Association 52 (1983): 59-82.

. "Productivity, Industrial Restructuring and the Deglomeration of American Manufacturing." Technology, Regions and Policy, edited by J. Rees, 141-170. Totown, N. J.: Rowman and Allanheld, 1986. 
"Capital Restructuring, Government Policy and the Decentralization of American Manufacturing." Government Policy and Industrial Change, edited by D. Gibbs, 73-91. London: Routledge, 1989.

National Science Board. Science Indicators 1980. Washington, D.C.: U.S. Government Printing Office, 1981.

Norcliffe, G. B. "A Theory of Manufacturing Places." Locational Dynamics of Manufacturing Activity, edited by L. Collins and D. F. Walker, 19-57. New York: John Wiley and Sons, 1975.

Norton, R. D., and J. Rees. "The Product Cycle and the Spatial Decentralization of American Manufacturing." Regional Studies 13 (1979): 141-151.

Park, S. O., and J. O. Wheeler. "The Filtering Down Process in Georgia: The Third Stage of the Product Life Cycle." Professional Geographer 35 (1983): 18-31.

Parr, J. B. "Models of City Size in an Urban System." Papers: Regional Science Association 25 (1970): 221-254.

. "A Population Density Approach to Regional Spatial Structure." Urban Studies 22 (1985a): 289-303.

. "The Form of the Regional Density Function." Regional Studies 19 (1985b): 535-546.

. "A Note on the Size Distribution of Cities Over Time" Journal of Urban Economics 18 (1985c): 199-212.

Parr, J. B., and C. Jones. "City Size Distributions and Urban Density Functions: Some Interrelationships." Journal of Regional Science 23 (1983): 283-307.

Pred, A. R. City Systems in Advanced Economies. New York: Halstead, 1977.

Rees, J. "Manufacturing Change, Internal Control and Government Spending in a Growth Region of the USA." Industrial Change, International Experience and Public Policy, edited by F. E. I. Hamilton, 155-174. London: Langman, 1978.

"Technological Change and Regional Shifts in American Manufacturing." Professional Geographer 31 (1979): 45-54.

Rees, J., R. Briggs, and R. Oakey. "The Adoption of New Technology in the American Machinery Industry." Regional Studies 18 (1984): 489-504.

Schmenner, R. W. Making Business Location Decisions. Englewood Cliffs, N. J.: Prentice-Hall Inc., 1982.

Struyk, R. J., and F. J. James, Jr. Intrametropolitan Industrial Location. Lexington, Mass.: D.C. Heath and Co., 1975.

Thompson, W. R. "The Economic Base of Urban Problems." Contemporary Economic Issues, edited by H.W. Chamberlin, 1-47. Homewood Hills, Ill.: Richard D. Irwin Inc., 1969. 
Thompson, W. R., and J. M. Mattilla. An Economic Model of Postwar State Industrial Development. Detroit: Wayne State University Press, 1959.

Till, T. "The Extent of Industrialization in Southern Nonmetropolitan Labor Markets in the 1960s." Journal of Regional Science 13 (1973): 453-461.

United States Department of Commerce. Census of Manufacturers. Washington, D.C.: Bureau of the Census, 1947, 1954, 1958, 1963, 1967, 1972, 1977, 1982.

United States Department of Commerce. Census of Population. Washington, D.C.: Bureau of the Census, 1950, 1960, 1970, 1980.

Vernon, R. "International Investment and International Trade in the Product Cycle." Quarterly Journal of Economics 80 (1966): 190-207. "The Product Cycle Hypothesis in a New International Environment." Oxford Bulletin of Economics and Statistics 41 (1979): 255-267.

Zelinsky, W. "Has American Industry Been Decentralizing: The Evidence for the 1930-54 Period." Economic Geography 38 (1962): 251-289. 